\title{
Ribosomal Protein S6 Kinase Alpha-2
}

National Cancer Institute

\section{Source}

National Cancer Institute. Ribosomal Protein S6 Kinase Alpha-2. NCI Thesaurus. Code C150309.

Ribosomal protein $\mathrm{S} 6$ kinase alpha-2 $(733 \mathrm{aa}, \sim 83 \mathrm{kDa})$ is encoded by the human RPS6KA2 gene. This protein plays a role in the modulation of transcription, cellular proliferation, differentiation, and survival. 